\title{
ЕФЕКТИВНІСТЬ ЛІКУВАННЯ ПАЦІЄНТІВ ІЗ ХРОНІЧНИМ ОБСТРУКТИВНИМ ЗАХВОРЮВАННЯМ ЛЕГЕНЬ I ОСТЕОАРТРИТОМ
}

\begin{abstract}
Резюме. Хронічне обструктивне захворювання легень (ХОЗЛ) - Хвороба XXI століття. Від ХОЗЛ страждає 210 млн людей в усьому світі, щорічно помирає від цієї хвороби 3 млн хворих. Під впливом різних фракторів (куріння, гази, пари хімічних сполук, продукти згоряння палива) розвивається запальний процес у тканинах легень, який на тлі морфологічних змін в них забезпечує розвиток системних запальних проявів. Системне запалення розглядають як складову патогенезу ХОЗЛ, що забезпечує розвиток і прогресування численних ускладнень захворювання. Серед великої кількості ускладнень та системних ефектів ХОЗЛ досить часто виділяють розвиток остеопорозу як основи остеоартриту (ОА).

Мета дослідження - вивчити ефективність використання феенспіриду гідрохлориду при спільному перебігу ХОЗЛ й ОА.

Матеріали і методи. Обстеження пацієнтів проводили на базі пульмонологічного та ревматологічного відділень Полтавської обласної клінічної лікарні імені М. В. Скліфосовського. Дослідження виконували на базі Науково-дослідного інституту генетичних та імунологічних основ розвитку патології та фрармакогенетики вищого державного навчального закладу України "Українська медична стоматологічна академія". Проводили оцінку клінічних показників, фрункції зовнішнього дихання (ФЗД) за допомогою спірографрічного апарату “Кардіо + +" (Україна), визначення IL-1 в в сироватці крові обстежених хворих виконували за допомогою методу імуносрерментного аналізу.

Результати досліджень та їх обговорення. Обстежено 33 хворих середнього віку $((54,4 \pm 3,1)$ року) із загостренням ХОзл (клінічна група B - GOLD II) в поєднанні з ОА. Тривалість захворювання ХОЗЛ становила $(16,2 \pm 2,1)$ року. Серед пацієнтів чоловіків було 28 (84,8 \%), жінок - 5 (15,2 \%). Усі хворі курили, стаж куріння становив $(32,4 \pm 2,9)$ пачко-року. При ОА, який був наявний у пацієнтів основної групи в фазі нестійкої ремісії, в патологічний процес були залучені великі суглоби - колінні, плечові, гомілковоступневі. Залежно від обраного варіанту лікування, хворих поділили на 2 репрезентативні групи - перша і друга. У комплексному лікуванні ХОЗЛ в поєднанні з ОА приділяється увага протизапальній терапії, зокрема дії френспіриду гідрохлориду.

Висновки. 3 даних випливає, що у пацієнтів із загостренням ХОЗЛ в поєднанні з ОА у сироватці крові вміст IL-1 $\beta$ перевищує рівень у здорових осіб в 14,6 раза ( $<0,001)$. Встановлено, що додаткове застосування фенспіриду гідрохлориду під час загострення ХОЗЛ в поєднанні з ОА сприяє зменшенню концентрації IL-1ß в сироватці крові пацієнтів, вказує на зниження системного запалення і сприяє пролонгації ремісії, поліпшенню результату лікування пацієнтів із зазначеною коморбідністю.
\end{abstract}

Ключові слова: хронічне обструктивне захворювання легень; остеоартрит; коморбідність; протизапальна терапія; френспіриду гідрохлорид.

ВСТУП Хронічне обструктивне захворювання легень (ХОЗЛ) на сьогодні є одним із найпоширеніших захворювань людини, від якого, за даними ВООЗ, страждає 0,8 \% населення планети [1]. Супутні захворювання змінюють хід ХОЗЛ, спостерігається розвиток його системних ефектів, таких, як прогресуюча кахексія, вторинна анемія, системне запалення, системний остеопороз [2]. Останній, поряд із системним запаленням, може бути несприятливим предиктором розвитку остеоартриту (ОА).

Найбільш небезпечним станом при ХОЗЛ є інфекційне загострення, яке значно погіршує якість життя хворого, вимагає збільшення обсягу певних базисних засобів, погіршує прогноз захворювання. Цитокіни, простагландини і лейкотрієни є важливими компонентами місцевого та системного запалення. Оцінку запальних процесів можна проводити за динамікою концентрації інтерлейкі-

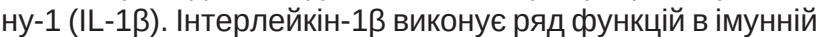
системі: ініціює і регулює імунні процеси, бере участь у розвитку гострого і хронічного запалення, в кістковій резорбції [3].

Системному запаленню при ОА приділяють істотне значення. Цитокіновий механізм є учасником будь-якого запалення, у тому числі й при OA [4]. Однак вміст IL-1, зокрема IL-1 $\beta, €$ недостатньо вивченим не тільки при загостренні ХОЗЛ, але і при загостренні ХОЗЛ в поєднанні з ОА.

Лікування при ХОЗЛ здійснюється з використанням комплексу базисних засобів, рекомендованих існуючими протоколами (наказ МОЗ України № 555 від 30.10.2013 р зі змінами від 16.04.2014 р № 270) з переважно місцевою дією в трахеобронхіальному дереві. При ОА застосовують нестероїдні протизапальні препарати (НПЗП), хондро- протектори, місцеве лікування. Пошук і розробка методів лікування поєднаного перебігу ХОЗЛ і ОА з урахуванням додаткового впливу на всі механізми, що підтримують запалення, $є$ актуальним.

На сьогодні одним із найбільш ефективних протизапальних засобів у лікуванні ХОЗЛ з ОА є фенспірид. Провідними перевагами даного препарату, порівняно 3 традиційними НПЗП, є його висока ефективність і мінімальна кількість побічних ефектів. Фенспірид має протизапальну дію шляхом пригнічення продукції ряду цитокінів (фрактора некрозу пухлин (ФНП) - $\alpha$, інтерлейкінів (ІЛ) -1, ІЛ-2, ІЛ-6, ІЛ-8 та інтерферону), які мають значення у розвитку запалення й імунної відповіді організму, мають антиагрегантну дію, що покращує стан мікроциркуляторного русла $[5,6]$.

Метою роботи було вивчення ефективності використання фенспіриду гідрохлориду при спільному перебігу ХОЗЛ Й ОА.

МАТЕРІАЛИ I МЕТОДИ Обстеження пацієнтів проводили на базі пульмонологічного та ревматологічного відділень Полтавської обласної клінічної лікарні імені М. В. Скліфосовського. Дослідження виконували на базі Науково-дослідного інституту генетичних та імунологічних основ розвитку патології та фрармакогенетики вищого державного навчального закладу України "Українська медична стоматологічна академія".

Проводили оцінку клінічних показників, фрункції зовнішнього дихання (ФЗД) за допомогою спірографрічного апарату "Кардіо"+" (Україна), визначення IL-1 в в сироватці крові обстежених хворих виконували за допомогою методу імуноферментного аналізу. 
Обстежено 33 хворих середнього віку $((54,4 \pm 3,1)$ року $)$ із загостренням ХОЗЛ (клінічна група B - GOLD II) в поєднанні з ОА. Тривалість захворювання ХОЗЛ становила $(16,2 \pm 2,1)$ року. Серед пацієнтів чоловіків було 28 (84,8 \%), жінок - 5 (15,2 \%). Усі хворі курили, стаж куріння становив $(32,4 \pm 2,9)$ пачко-року. При ОА, який був наявний у пацієнтів основної групи в фразі нестійкої ремісії, в патологічний процес були залучені великі суглоби колінні, плечові, гомілковоступневі. Залежно від обраного варіанту лікування, хворих поділили на 2 репрезентативні групи - перша і друга.

Пацієнти першої групи отримували тільки базисну терапію ХОЗЛ відповідно до існуючих протоколів (комбіновані бронходилататори короткої дії, бронходилататори тривалої дії, муколітики, антибіотики-макроліди, при необхідності - системні кортикостероїди коротким курсом, а також - хондропротектори), а другої групи - до комбінованої терапії додавали фенспириду гідрохлорид 80 мг 2 рази на добу протягом 12 днів.

Контрольну групу склали 25 практично здорових осіб у тому ж віковому діапазоні. Результати отриманих досліджень були оброблені на персональному комп'ютері за допомогою пакета статистичних програм SPSS для Windows.

РЕЗУЛЬТАТИ ДОСЛІДЖЕНЬ ТА ЇХ ОБГОВОРЕННЯ Усі пацієнти 3 інфекційним загостренням ХОЗЛ в поєднанні з ОА скаржилися на виражену постійну задишку в спокої, яка посилювалася при незначному фрізичному навантаженні, підвищену температуру тіла до 37,4$37,8 \mathrm{C}^{\circ}$, надсадний кашель із гнійним мокротинням, слабкість, роздратованість. При додаванні до базисної терапії френспіриду у хворих із констеляцією ХОЗЛ і ОА регрес захворювання (зменшення кашлю) спостерігався

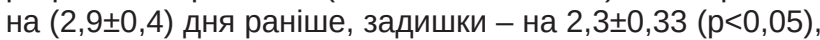
ніж у групі порівняння, збільшувалась толерантність до фрізичних навантажень.

Рівень обсягу фрорсованого видиху за першу секунду $\left(O Ф B_{1}\right)$ у пацієнтів першої групи склав $(53,4 \pm 3,9) \%$, тест на оберненість бронхіальної обструкції в тесті з бронхолітиком перед лікуванням надав результат $(2,9 \pm 0,3) \%$, сатурація кисню - $(92,3 \pm 2,4) \%$. Порівняно з хворими, які отримували тільки базисну терапію, мало місце достовірне зростання МШВ25 ( $<<0,05)$.

\section{СПИСОК ЛІТЕРАТУРИ}

1. Глобальна стратегія: діагностика, лікування та профрілактика хронічної обструктивної хвороби легень : доповідь робочої групи Національного Інституту Серця, Легень і Крові. - ВООЗ, 2014.

2. García-Olmos L. Comorbidi tyinpatients with COPD infamily practice / L. García-Olmos, A. Alberquilla, V. Ayalaetal // BMC Fam. Pract. - 2013. - Jan 16. - Vol. 14. - P. 11.

3. Блюм Н. Е. Особливості цитокінового балансу при хронічної обструктивної хвороби легень / Н. Е. Блюм // Російський медичний журнал. - 2016. - № 22. - С. 1620-1621.
Концентрація IL-1ß у сироватці крові в осіб основної групи була вище аналогічної в практично здорових осіб у 14,6 раза $(\mathrm{p}<0,001)$. Між вмістом IL-1 $\beta$ в сироватці крові хворих із констеляцією ХОЗЛ і ОА і значеннями їх ОФВ був міцний негативний кореляційний зв'язок ( $r=-0,812$; p<0,05), що вказувало на тісний зв'язок маркерів запалення зі станом бронхіальної прохідності.

ОФВ після лікування у пацієнтів першої групи дорівнював $(57,6 \pm 4,2) \%$, другої - $(59,9 \pm 3,9) \%$, зворотність бронхіальної обструкції в обох групах дещо підвищилася: у першій - на $(3,2 \pm 0,7) \%$, в другій - на $(3,6 \pm 0,5) \%$.

Після курсу терапії у пацієнтів першої групи рівень IL-1 $\beta$ знизився в 1,7 раза ( $<<0,01)$. Після проведення лікування з додаванням до базової терапії френспириду в осіб другої групи це зниження було більш значущим - у 2,8 раза $(p<0,001)$. Зменшення концентрації інших медіаторів запалення під впливом зазначеного препарату спостерігалося і в інших дослідженнях. Очевидно, плейотропний протизапальний ефрект фенспиріду гідрохлориду забезпечив і зниження продукції IL-1 $\beta$. Міцний негативний кореляційний зв'язок ( $r=-0,812 ; p<0,05)$ між вмістом IL-1 $\beta$ у сироватці крові хворих основної групи і значеннями їх ОФВ який був визначений до лікування, після нього став середньонегативним у хворих першої групи $(r=-0,681 ; p<0,05)$ i слабким в осіб другої групи (r=- 0,475; $p<0,05)$. Термін госпіталізації пацієнтів першої групи становив $(14,3 \pm 0,4)$ дня, другої групи - трохи менше і склав $(12,9 \pm 0,5)$ дня.

Важливим результатом проведення терапії загострення ХОЗЛ із додатковим застосуванням фенспіриду було визначення часу до наступного загострення ХОЗЛ, так як саме частота загострень визначає прогноз захворювання. У першій групі цей час становив $(10,3 \pm 0,9)$ місяця, в другій групі - $(15,7 \pm 1,1)$ місяця.

Висновки 1. 3 даних випливає, що у пацієнтів із загостренням ХОЗЛ в поєднанні з ОА у сироватці крові вміст IL-1 $\beta$ перевищує рівень у здорових осіб в 14,6 раза $(p<0,001)$.

2. Встановлено, що додаткове застосування фенспіриду гідрохлориду під час загострення ХОЗЛ в поєднанні з ОА сприяє зменшенню концентрації IL-1ß в сироватці крові пацієнтів, вказує на зниження системного запалення і сприяє пролонгації ремісії, поліпшенню результату лікування пацієнтів із зазначеною коморбідністю.
4. Хайменова Г. С. Сучасний підхід до профрілактики загострень та лікування хворих на ХОЗЛ у поєднанні з остеоартритом / Г. С. Хайменова // Актуальні проблеми сучасної медицини // Вісник української медичної стоматологічної академії. - Полтава, 2016. - Т. 16, вип. 2 (54) - С. 192-195.

5. Chodorowski Z. Acute intoxication with fenspiride / Z. Chodorowski, J. SeinAnand, R. Korolkiewicz // PrzeglLek. - 2014. - Vol. 61 (4). - P. 435-436.

6. Оценка эффрективности терапии пациентов с сочетанным течением ХОЗЛ и остеоартритом / Г. С. Хайменова, Л. Н. Шилкина, М. Ю. Бабанина [и др.] // WiadomostiLekarskie. - Констанцин-Єзьорна (Польша), 2016, tomLXIX, nr 2 (cz.II). - C. 214-218. 


\section{EFFECTIVENESS OF TREATMENT OF CHRONIC OBSTRUCTIVE PULMONARY DISEASE AND OSTEOARTHRITIS}

Summary. Chronic obstructive pulmonary disease (COPD) is a disease of the 21 st century. COPD affects 210 million people everywhere, every year 3 million people die of this disease. Under the influence of various factors (smoking, gases, a pair of chemical compounds, products of combustion of fuel), an inflammatory process develops in the tissues of the lungs, which, in the background of morphological changes in them, provides the development of systemic inflammatory manifestations. Systemic inflammation is considered as a component of the pathogenesis of COPD, which ensures the development and progression of numerous complications of the disease. Among the large number of complications and systemic effects of COPD, the development of osteoporosis as the basis of osteoarthritis $(\mathrm{OA})$ is often isolated.

The aim of the study - to investigate the effectiveness of the use of fenspiride hydrochloride in the course of the combined course of COPD and OA.

Materials and Methods. Examination of patients was conducted on the basis of pulmonologic and rheumatologic departments of the Poltava Regional Clinical Hospital named after M. V. Sklifosovskyi. The research was carried out on the basis of the Research Institute of Genetic and Immunological Foundations of the Development of Pathology and Pharmacogenetics of the Ukrainian State Medical Education Institute "Ukrainian Medical Dentistry Academy". The evaluation of clinical parameters, function of external respiration was performed with the help of a cardiologic apparatus "Cardio ++" (Ukraine), determination of IL-1 $\beta$ in blood serum of the examined patients was performed using the method of immunoassay analysis.

Results and Discussion. 33 patients with middle age $(54.4 \pm 3.1)$ years with exacerbation of COPD (Clinical group B - GOLD II) in combination with OA were examined. Duration of COPD was (16.2 \pm 2.1$)$ years. Among patients, men were $28(84.8 \%)$, and women $-5(15.2 \%)$. All patients smoked, the experience of smoking was $(32.4 \pm 2.9)$ pack years. In OA, which was available in patients of the main group in the phase of unstable remission, large joints - knee, shoulder, and leg joints - were involved in the pathological process. Depending on the chosen treatment option, the patients were divided into 2 representative groups - the first and the second. In the complex treatment of COPD in combination with OA attention is given to anti-inflammatory therapy, in particular the action of fenspirid hydrochloride.

Conclusions. From our data it follows that in patients with exacerbation of COPD in combination with OA in serum, the content of IL-1 $\beta$ exceeds the level in healthy persons by 14.6 times $(p<0.001)$. It has been established that the additional use of fenspiride hydrochloride during exacerbation of COPD in combination with OA promotes the decrease of the concentration of IL-1 in serum of patients, indicates a decrease in systemic inflammation and promotes prolongation of remission, improvement of the outcome of treatment of patients with the indicated comorbidity.

Key words: chronic obstructive pulmonary disease; osteoarthritis; comorbidity; anti-inflammatory therapy; fenspiride hydrochloride.

СВ. Н. Ждан, М. М. Потяженко, Г. С. Хайменова, Н. А. Люлька, Н. Л. Соколюк, Т. В. Дубровинская ВГУз Украины “Украинская медицинская стоматологическая академия", г. Полтава

\section{ЭФФЕКТИВНОСТЬ ЛЕЧЕНИЯ ПАЦИЕНТОВ С ХРОНИЧЕСКИМ ОБСТРУКТИВНЫМ ЗАБОЛЕВАНИЕМ ЛЕГКИХ И} ОСТЕОАРТРИТОМ

Резюме. Хроническое обструктивное заболевание легких (ХОЗЛ) - болезнь XXI века. От ХОБЛ страдает 210 млн человек во всем мире, ежегодно умирает от этой болезни 3 млн больных. Под влиянием различных факторов (курение, газы, продукты сгорания топлива) развивается воспалительный процесс в тканях легких, который на фоне морфологических изменений в них обеспечивает развитие системных воспалительных проявлений. Системное воспаление рассматривается как составная часть патогенеза ХОБЛ, которая обеспечивает развитие и прогрессирования многочисленных осложнений заболевания. Среди большого количества осложнений и системных эфффектов ХОБЛ достаточно часто выделяют развитие остеопороза как основы остеоартрита (ОА).

Цель исследования - изучить эффективность использования фенспирида гидрохлорида при совместном течении ХОБЛ и ОА. Материалы и методы. Обследование пациентов проводили на базе пульмонологического и ревматологического отделений Полтавской областной клинической больницы имени Н. В. Склисоосовского. Исследования проводили на базе Научно-исследовательского института генетических и иммунологических основ развития патологии и фармакогенетики высшего государственного учебного заведения Украины “Украинская медицинская стоматологическая академия". Проводили оценку клинических показателей, функции внешнего дыхания (ФВД) с помощью спирограсрического аппарата "Кардио ++" (Украина), определение IL-1ß в сыворотке крови обследованных больных выполняли с помощью метода иммуноферментного анализа. Результаты исследований и их обсуждение. Обследовано 33 больных среднего возраста $((54,4 \pm 3,1)$ года) с обострением ХОБЛ (клиническая группа В - GOLD II) в сочетании с ОА. Длительность заболевания ХОБЛ составила $(16,2 \pm 2,1)$ года. Среди пациентов мужчин было 28 (84,8 \%), женщин - 5 (15,2 \%). Все больные курили, стаж курения составил $(32,4 \pm 2,9)$ пачко-лет. При ОА, который присутствовал у пациентов основной группы в фазе нестойкой ремиссии, в патологический процесс были вовлечены крупные суставы - коленные, плечевые, голенестопные. В зависимости от выбранного варианта лечения, больных разделили на 2 репрезентативных группы - первая и вторая. В комплексном лечении ХОБЛ в сочетании с ОА уделяется внимание противовоспалительной терапии, в частности действии фенспирида гидрохлорида.

Выводы. Из данных следует, что у пациентов с обострением ХОБЛ в сочетании с OA в сыворотке крови содержание IL-1ß превышает уровень в здоровых лиц в 14,6 раза ( $<<0,001)$. Установлено, что дополнительное применение фенспирида гидрохлорида во время обострения ХОБЛ в сочетании с ОА способствует уменьшению концентрации IL-1 $\beta$ в сыворотке крови пациентов, указывает на снижение системного воспаления и способствует пролонгации ремиссии, улучшению результата лечения пациентов с указанной коморбидностью.

Ключевые слова: хроническое обструктивное заболевание легких; остеоартрит; коморбидность; противовоспалительная терапия; фенспирида гидрохлорид. 